There is evidence that prostaglandins modulate protein synthesis and degradation in the incubated rat muscle [16], and that prostaglandins might be involved in the stimulation induced by insulin on muscle protein synthesis $[4,5]$. However, prostaglandins do not seem to mediate changes in glucose transport or uptake induced by exercise or insulin. The major contradictory findings existent in the literature concern the results obtained in the human forearm as compared with those reported in the perfused or incubated rat muscle. Although they are very different models, it seems highly unlikely that the mechanisms by which insulin or exercise stimulate glucose uptake and transport are different in human and in rat skeletal muscle or when comparing models in vivo and in vitro. In human studies, attention should be paid to possible indirect effects of bradykinin and prostaglandin inhibitors on muscle. In any case, further and more elaborate studies are needed in order to elucidate the molecular basis for insulin and exercise action on glucose uptake in skeletal muscle.

\section{Antonio ZORZANO}

Unidad de Bioquimica y Biologia Molecular B, Departamento de Bioquimica y Fisologia, Facultad de Biologia, Universidad de Barcelona, Avda. Diagonal 645, Barcelona 08071, Spain

1. Hartl, W. H. (1987) Biochem. J. 248, 621-622

2. Dietze, G. \& Wicklmayr, M. (1977) FEBS Lett. 74, 205-208

3. Wicklmayr, M., Dietze, G., Mayer, L., Bottger, I. \& Grunst, J. (1979) FEBS Lett. 98, 61-65

4. Reeds, P. J. \& Palmer, R. M. (1983) Biochem. Biophys. Res. Commun. 116, 1084-1090

5. Reeds, P. J., Hay, S. M., Glennie, R. T., Mackie, W. S. \& Garlick, P. J. (1985) Biochem. J. 227, 255-261

6. Zorzano, A., Balon, T. W., Jakubowski, J. A., Goodman, M. N., Deykin, D. \& Ruderman, N. B. (1986) Biochem. J. 240, 437-443

7. Smith, D. M. \& Sugden, P. H. (1987) Biochem. J. 243, 473-479

8. Berger, M., Hagg, S. \& Ruderman, N. B. (1975) Biochem. J. 146, 231-238

9. Constable, S. H., Favier, R. J., Uhl, J. \& Holloszy, J. O. (1986) J. Appl. Physiol. 61, 881-884

10. Leighton, B., Budohoski, L., Lozeman, F. J., Challiss, R. A. J. \& Newsholme, E. A. (1985) Biochem. J. 227, 337-340

11. Maizels, E. Z., Ruderman, N. B., Goodman, M. N. \& Lau, D. (1977) Biochem. J. 162, 557-568

12. Ploug, T., Galbo, H. \& Richter, E. A. (1984) Am. J. Physiol. 247, E726-E731

13. Wallberg-Henriksson, H. \& Holloszy, J. O. (1984) J. Appl. Physiol. 57, 1045-1049

14. Nesher, R., Karl, I. E. \& Kipnis, D. M. (1985) Am. J. Physiol. 249, C226-C232

15. Zorzano, A., Balon, T. W., Goodman, M. N. \& Ruderman, N. B. (1986) Am. J. Physiol. 251, E21-E26

16. Rodemann, H. P. \& Goldberg, A. L. (1982) J. Biol. Chem. 257, 1632-1638

\section{Nomenclature of phosphoenolpyruvate carboxykinase}

Phosphoenolpyruvate carboxykinase is the name given to three enzymes catalysing reversible conversion of phosphoenolpyruvate to oxaloacetate (Dixon \& Webb, 1979; Enzyme Nomenclature, 1984). These enzymes differ with respect to the acceptor of the phosphate group, which is GDP or IDP for the enzyme from animal tissues (EC 4.1.1.32); inorganic phosphate for the bacterial enzyme (EC 4.1.1.38) and ADP for the enzyme from higher plants and some microbes (EC 4.1.1.49). The name carboxykinase probably conveys its dual function, i.e. $\mathrm{CO}_{2}$ fixation and phospho group transfer. In literature the enzyme had been called oxaloacetate synthesizing enzyme (Stickland, 1959); oxaloacetate carboxylase (Utter \& Kurahashi, 1954); oxaloacetate decarboxylase (Corwin, 1959); phosphoenolpyruvate carboxytransphosphorylase (Siu et al., 1961 ; Utter \& Kolenbrander, 1972; Basu \& Malik, 1985) and phosphopyruvate carboxylase (Cannata \& Stoppani, 1963). The name phosphoenolpyruvate carboxykinase does not seem to be correct since it emphasizes the phospho group transfer which is not the primary reaction it catalyses; moreover, $\mathrm{CO}_{2}$ is fixed in one direction while the phospho group is transferred in the reverse direction. I, therefore, suggest that the enzyme should either be called phosphoenolpyruvate carboxylase (GTP or ATP or $\mathrm{PP}_{\mathrm{i}}$-forming) or oxaloacetate kinase (decarboxylating, GDP or ADP or $\mathrm{P}_{\mathrm{i}}$-forming).

\section{S. K. SINGLA}

Department of Biochemistry, Punjab Agricultural University, Ludhiana-141 004, India

Basu, A. S. \& Malik, C. P. (1985) Biol. Rev. 60, 357-401

Cannata, J. J. B. \& Stoppani, A. O. M. (1963) J. Biol. Chem. 238, 1919-1927

Corwin, L. M. (1959) J. Biol. Chem. 234, 1338-1341

Dixon, M. \& Webb, E. C. (1979) The Enzymes, 3rd edition, pp. 922-923, Longman Group, London

Enzyme Nomenclature (1984) Recommendations (1984) of the Nomenclature Committee of the International Union of Biochemistry, pp. 398-401, Academic Press, New York

Siu, P. M. L., Wood, H. G. \& Stjernholm, R. L. (1961) J. Biol. Chem. 236, PC21-PC22

Stickland, R. G. (1959) Biochem. J. 73, 660-665

Utter, M. F. \& Kolenbrander, H. M. (1972) in The Enzymes (Boyer, P. D., ed.), pp. 136-168, Academic Press, New York

Utter, M. F. \& Kurahashi, K. (1954) J. Biol. Chem. 207, 787-802

Received 8 April 1987

Received 4 August 1987 